\title{
Penerimaan Dakwah Keagamaan Mubaligh Tradisional dalam Masyarakat Korban Gempa Bumi
}

\author{
Nelmaya1, Ali Rahman², SilfiaHanani *3 \\ 1,2,3 IAIN Bukitinggi, Indonesia, \\ *Correspondence Adress, Email : silfia_hanani@yahoo.com \\ 1Email: nelmaya@gamail.com 2Email: Ali_rahman@gmail.com
}

DOI: https://doi.org/10.15548/turast.v7i1.789

(Diterima: 20 Februari 2019. Disetujui: 24 Juni 2019. Diterbitkan: 30 Juni 2019)

\begin{abstract}
Abstrct
This study aims to describe the influence of traditional religious elites (Mubaligh) in Nagari Tandikek, Patamuan sub-district, Padang Pariaman district, which experienced an earthquake outside of September 30, 2009. Qualitative research type is used to collect the data. Observation and interview techniques are used to collect the data. The result shows that the traditional religious leaders are very influential in the Tandikek community. They have transformative and communicative approaches which are very easily understood by the communities. In addition, religious elites are also able to become a reference figure in acting and behaving. It is concluded that religious elites has important role in stimulating communities.
\end{abstract}

Keywords: Earthquake, Mubaligh, Tandikek

\section{PENDAHULUAN}

Gempa bumi yang terjadi pada tanggal 30 September 2009 di Sumatera Barat, merupakan gempa bumi yang menelan korban dan kerugian yang tidak tanggung-tanggung, merusak inpra dan supra struktural yang sangat besar dampaknya terhadap kehidupan masyarakat setempat. Dengan demikian gempa bumi ternyata telah merubah realitas sosial dan keagamaan masyarakat (Gazali \& Andy, 2017; Nelmaya, 2018). Di balik perubahan itu yang paling tergoncang adalah mentalitas masyarakat, karena besarnya tekanan-tekanan yang dihadapi oleh masyarakat yang tertimpa musibah gempa tersebut, akibat mereka kehilangan anggota keluarga, harta kekayaan, pekerjaan dan traumatik dari pesritiwa itu sendiri.

Di sinilah diperlukan pelayanan keagamaan yang tepat sehingga pelayanan keagamaan itu dapat menjadi salah satu penyelamatan mentalitas dan perubahan taruamatik yang dialami oleh masyarakat korban. Secara pasti tentu tidak sama cara pelayanan agama antara 
dalam keadaan normal dengan keadaan pasca gempa, karena dari segi mentalitas dan psikologis mereka juga berbeda. Cara pendekatan pelayanan agama wilayah gempa pedalaman juga berbeda dengan kondisi masyarakat wilayah gempa perkotaan.

Sementara wilayah gempa pedalaman lebih banyak daripada perkotaan. Untuk melayani keagamaan jelas memiliki perbedaan. Pada masyarakat pedalaman pelayanan agama pada umumnya dilaksanakan oleh elite-elite agama tradisional yang diangkat oleh masyarakat setempat. Elite agama lokal tradisional itu, mampu berkomunikasi dengan masyarakat setempat (Achidsti, 2014; Rais, 2010). Sementara elite agama atau mubaligh yang datang ke dalam masyarakat lokal, tidak dapat membangun komunikasi, sehingga peran dakwah yang dilakukannya juga tidak dapat menjadi agent perubahan dan pemulihan mentalitas. Tidak sedikit mubalighmubaligh yang datang ke tengah masyarakat korban gempa pedalaman yang diusir oleh masyarakat setempat. Hanya mubaligh-mubaligh surau tradisional yang bisa diterima oleh masyarakat korban gempa bumi tersebut dalam melayani keagamaan mereka. Mengapa hal itu bisa terjadi. Tentu ini perlu kajian yang mendalam dan pelu menjawabnya dengan data-data yang kongkrit.

Penelitian ini bertujuan untuk mengungkapkan dan menganalisis penerimaan dakwah keagamaan mubaligh tradisional dalam mayarakat korban gempa bumi di Padang Pariaman.

\section{METODE PENELITIAN}

Wilayah yang dipilih untuk pelaksanaan riset adalah daerah yang terparah dari bencana gempa bumi 30 September 2009 di Kabupaten Padang Pariaman yaitu nagari Tandikek. Penelitian ini dilakukan dengan pendekatan kualitatif (Chariri, 2009; Mulyadi, 2011). Data dikumpulkan melalui pengamatan dan wawancara mendapa (indepth interview). Sedangkan data dianalisis dengan analisis kualitatif (Gunawan, 2013; Moleong \& Edisi, 2007; Sahidu, Muktasam, Nurjannah, \& Hayati, 2018; Yulisti, Kurniasari, \& Yuliaty, 2014)

\section{HASIL PENELITIAN DAN PEMBAHASAN}

\section{Pendekatan Mubalihg Tradisional}

Pendekatan yang paling utama dilakukan oleh ulama tradisional di Tandikek adalah pendekatan komunikatif, pendekatan ini dimana seorang ulama mendatangi dan bersama dengan masyarakatnya. Seorang ungku atau labai atau mubaligh (saat ini disebut urang siak) selalu bersedia mendatangi rumah-rumah daripada masyarakat yang memintanya. Di rumah-rumah itu terjadi komunikasi antara ulama dengan masyarakat atau umatnya. Di lihat dari ritualisasi, ada beberapa upacara atau ritual yang mengharuskan seorang ulama datang ke rumah umatnya di Tandikek, diantaranya adalah:

\section{Ketika kematian}

Semua kegiatan penyelenggaraan jenazah, pada umumnya sangat tergantung pada peran seorang urang 
siak. Orang siak sangat menentukan, karena semua prosesi itu semua sangat penuh dengan doa dan ritual, semua doa dan ritual itu dalam asumsi masyarakat lebih tinggi nilainya jika dibacakan dan dipimpin oleh urang siak, sehingga kehadiran urang siak sangat diperlukan. Di samping itu setelah usai penguburan, urang siak juga diminta untuk kembali ke rumah duka karena pasca penguburan dalam beberapa hari juga ada ritual kematian yang harus dipimpin oleh urang siak dalam jumlah 5-10 orang.

Diantara ritual setelah pengburan adalah, malam pertama sampai malam ketiga ada pembacaan doa yang harus dilakukan oleh urang siak di rumah duka. Hal ini selain bermakna ritual religius juga sebagai bentuk penyelamatan bathin bagi orang yang meninggal supaya rela terhadap kehilangan orang-orang yang dikasihinya.

Kemudian pada hari ke tujuh setelah penguburan yang dinamakan manujuh hari urang siak juga harus kembali ke rumah duka untuk membacakan doa-doa. Ia berkumpul lagi dengan jemaahnya. Setelah manujuh hari ada lagi setelah itu urang siak datang yakni ketika 14 hari pasca penguburan yang disebut dengan manduo kali tujuh, dilanjutkan dengan hari ke 40 hari yang disebut dengan ampek puluh hari dan hari ke 100 yang disebut dengan maratuih hari semuanya itu ada pembacaan doa oleh urang siak.

\section{Tradisi-tradisi}

Urang siak juga sering dipanggil untuk membacakan doa dalam berbagai upacara-upacara dan peringatan hari besar. Doa tersebut selain ditujukan sebagai rasa syukur juga sebagai bentuk pengharapan-pengharapan yang diminta pada Tuhan, sehingga seorang urang siak sering sekali dipanggil oleh masyarakat untuk datang ke rumahnya untuk membacakan doa. Diantara tradisi mendoa dengan urang siak di rumah masyarakat di Tandikek adalah, ketika panen padi di sawah sudah sampai di rumah, dinamakan doa makan kapalo bareh, doa setelah memanen kelapa di ladang pusaka dinamakan doa memakan harato, doa melepas nazar dinamakan doa malapeh niat, doa di bulan Rajab dinamakan doa sumareh, doa di bula Syakhban dinamakan doa bulan lamang, doa dibulan Maulid dinamakan doa mauluik dan lain-lain.

Doa-doa itu dalam tradisi masyarakat setempat harus dibacakan oleh seorang urang siak. Dimana setiap urang siak yang membackan doa selalu ada acara makan bersama duduk bajamba dan ada sedekah yang diberikan kepada urang siak. Khusus doa di bulan Rajab, Syakban dan Maulid itu hampir setiap rumah melakukan kekgaitan doa dengan urang siak tersebut.

Khusus di bulan Syakban, semua urang siak yang diminta oleh masyarakat untuk datang mendoa ke rumahnya pasti diberi lamang satu batang atau dua batang, sehingga urang siak selain membawa uang juga membawa makanan-makanan minimal sebatang lamang. Hal ini merupakan salah satu bentuk penghargaan dan ucapan terima kasih daripada yang meminta bacakan doa kepada urang siak.

Dengan cara-cara seperti itu urang siak sangat sering sekali mendatangi rumah umatnya, sehingga hubungan 
seperti ini dapat menjadi sarana komunikasi dan saling mengenal seorang elite agama dengan umatnya. Hal seperti ini sangat membantu masyarakat dalam perihal keagamaan dan sekaligus sebagai salah satu bentuk daripada kedekatan seorang ulama dengan umatnya. Hubungan dan komunikasi ini masih berlaku sampai saat sekarang, walupun nagari ini dilanda bencana gempa. Bahkan dengan adanya cara dan tradisi seperti itu menyebabkan masyarakat nagari Tandikek sangat sulit menerima kedatangan elite-elite agama dari luar yang tidak mereka kenali.

Disamping itu, juga dapat menjadi salah satu bentuk proteksi masyarakat dari bentuk masuknya aliran-aliran lain ke dalam masyarakat. Kedekatan seorang ulama dengan umatnya ini, sangat berguna dalam membangun satu kekuatan keagamaan dalam masyarakat. Masyarakat sangat sensitif terhadap aliran-aliran yang baru mereka dengar dan peroleh.

\section{Ritual Bersama}

Selanjutnya pendekatan ulama terhadap umatnya di Tandikek juga terjadi melalui kegiatan ritual bersama. Ada beberapa ritual yang dilakukan secara bersama, dimana antara seorang ulama dan umatnya berkumpul bersama dalam beribadah. Seorang ulama menuntun secara bijak umatnya dan berkomunikasi dengan sangat harmonis. Ada beberapa ritual bersama yang dilakukan di Tandikek diantaranya adalah:

\section{Sumbayang 40}

Sumbayang ampek puluah, merupakan suatu tradisi ibadah bagi penganut traikat di Ulakan Pariaman. Tradisi ini, merupakan hasil dari perenungan perjalanan sejarah Syekh Burhanuddin sebagai guru tarikat ketika kembali dari menunutut ilmu dari Aceh pada abad ke-18. Setelah itu sumbayang ampek puluh, dikembangkan oleh murid-murid tarikatnya di surau-surau kecil di sekeliling makam Syekh Burhanuddin. Tradisi shalat ini, adalah melaksanakan shalat wajib lima waktu berjemaah selama 40 hari di sebuah surau seorang guru tarikat, jika satu shalat saja tidak berjemaah maka terputus amalam dari tradisi tersebut. Ia harus mengulang kembali. Tradisi ini dilakukan berkelompokkelompok, jumlahnya tidak terbatas hanya disesuaikan dengan kemampuan surau menampung pengikutnya. Tradisi ini, tidak hanya diikuti oleh masyarakat sekitar surau, malahan juga diikuti oleh masyarakat yang diluar daerah. Di mana selama empat puluh hari itu, ia mondok di surau tidak kembali ke rumah. Jadi surau betul-betul menjadi media penanganan masalah keagamaan masyarakat.

Di Tandikek setelah pasca gempa bumi ini sembayang 40 semakin banyak di lakukan di surausurau, tidak hanya di surau seorang tuanku tetapi juga surau-surau kaum. Sebelum gempa surau-surau kaum ini hanya dibuka dan punya kegiatan ketika memperingati hari-hari besar Islam, tetapi pasca gempa bumi surau-surau kaum melakukan 
kegiatan ini. Dimana banyak perempuan menjadi pesertanya, sehingga surau pasca gempa juga terlihat sebagai perlindungan bagi kaum perempuan.

Namun, dalam konteks hubungan seorang ulama dengan umatnya semakin terlihat adanya hubungan yang inten setiap hari. Ulama dan umatnya sering bersama, berkomunikasi dan mengontrol prilaku umatnya. Kondisi ini pula yang menjadikan pasca gempa ini ulama dan umat semakin dekat dan umat semakin tidak mudah menerima kedatangan ulama dan aliran-aliran yang baru saat sekarang ini.

Sumbayang 40 di Tandikek ternyata juga terlihat fungsinya sebagai agent memperkuat silaturahmi diantara sesama masyarakat, karena mereka perkumpul dan beribadah secara bersama di surau, bahkan bermalam di surau. Mereka saling berkomunikasi dan bercerita tentang berbagai kehidupan setelah menunaikan shalat berjemaah yang diimami oleh urang siak.

\section{Baminggu}

Baminggu merupakan kegiatan pendidikan keagamaan yang berlangsung pada hari-hari tertentu. Dimana gurunya adalah ulama traikat, sistem pendidikannya berhalaqah yang diikuti oleh siapa saja. Baminggu ini, adalah kegiatan tradisi kependidikan yang memperkuat internalisasi ajaranajaran yang disampaikan oleh seorang ulama. Internalisasi ajaran ini, berdampak terhadap penguatanpenguatan keagamaan masyarakat.

Baminggu merupakan kegiatan ceremah tradisional yang dilakukan dalam waktu yang sudah dijadwalkan setiap minggunya. Kegiatan ini dilaksanakan di Tandikek di surausurau "ungku", dimana setiap minggunya "ungku" memberikan pengajian agama diikuti oleh jemaah yang ramai. Biasanya baminggu ini dilakukan sesudah shalat isya setiap malam Jumat.

Artinya dengan adanya kegiatan baminggu ini, satu kali dalam seminggu umat mendapatkan pendidikan agama dari "ungkunya". Di samping itu, ungku dan umatnya semakin dekat dan semakin saling kenal mengenal. Bahkan dengan adanya kegiatan baminggu ini umatnya semakin fanatik terhadap ungkunya.

Kefanatikan ini, menjadikan umat semakin mengenal ajaran ungku dan sangat sulit dilakukan perubahan dan sangat tidak mudah mempengaruhui masalah keagamaan masyarakat Tandikek. Masyarakat memiliki kefanatikan ajaran-ajaran agama yang disampaikan ungkunya. Jika ada ajaran yang berbeda dari yang diajarkan ungku, masyarakat dengan sangat cepat untuk menolaknya karena dianggap tidak sesuai dengan ajaran yang mereka terima dari ungku.

\section{Basuluak}

Sedangkan basuluak adalah tradisi ibadah yang bentul-betul hanya ditujukan untuk pensucian diri seseorang. Ia dilaksanakan penuh 
khitmat, hingga pengikut tradisi ini betul-betul membangun tamsya ke esetorikannya. Melupakan dimensi keduniaannya. Tradisi suluak dianggap menjadi penyeimbang antara kehidupan dunia dan ukhrawi.

Setiap bulan Ramadhan suluak dilakukan di surau-surau ulama. Satu bulan penuh kegiatan suluk itu berjalan di surau dengan berbagai ritual ibadahnya. Dimana seluruh pesertanya tidur di surau dan memasak bersama. Pada umumnya banyak diikuti oleh perempuanperempuan tua, sehingga surau pada waktu itu mirip seperti panti jumpo.

Suluk itu dipimpin langsung oleh ulama pemilik surau, ia seorang ulama tarikat. Di Tandikek pada umumnya ulamanya menganut tarikat Syatariah. Suluk itu bahagian yang terpenting dari tarikat. Selama suluk pesertanya terfokus pada kegiatan ibadah.

Terkait dengan tradisi-tradisi ibadah itu menurut (Hidayatulloh \& Farida, 2018; HS, 2013) tradisi ritual menjadi keharusan dari semua aliranaliran agama dan kepercayaan, hingga dapat disimpulkan tidak ada agama dan aliran-alirannya tidak memiliki tradisi ritual itu. Malahan tradisi ritual itu, menjadi simbol dan identitas dari sebuah aliran (Patty, 2014). Ketika ia menjadi simbol, maka simbol itu diterima oleh masyarakat, penerimaan simbol itu akan membangun integritas karena adanya ikatan-ikatan seseorang dengan kelompoknya dengan identitas yang diterimanya itu (Wekke, 2018). Menurut (Miharja, Mulyana, Izzan, \& Zakaria, 2017) tradisi ritual bisa menjadi fenomenologis keagmaan yang menyatukan sikap keagamaan masyarakat, ia tidak mendapat perlawanan tetapi diterima sebagai bagian dalam dunia sosialnya.

(Geertz, 1960; Khoiriyah, 2017), sebagai antropologi budaya pada dasarnya, juga mengatakan bahwa tradisi pengelolaan keagmaan sebenarnya ada pada semua agama. Penerimaan suatu aliran kegamaan, sangat dibantu oleh tradisi yang dibangun oleh keagamaan itu (Munip, 2012). Tradisi keagamaan itu, sebenarnya yang paling awal dibaca dan dinilai oleh seseorang jika ia mengenal dan menerima suatu agama atau aliran (Rakhmat, 2013). Oleh sebab itu, tradisi keagamaan itu harus mampu merekontruksi sistem nilai yang dapat mengakomodasi masyarakat yang tidak membenturkannya dengan budaya yang dimilikinya.

Dalam konteks ini, (Asmaya, 2003) mendefenisikan sebuah keharmonisan dalam keagamaan apabila pembinaan keagamaan dapat mengisi kekosongan tradisi yang ada dengan cara saling menghargai atau dapat dilakukan dengan pendekatanpendekatan tradisi yang dapat dan mudah dicerna oleh psikologis masyarakat. Mengingat masyarakat mana pun di dunia ini memiliki budaya, maka tidak mungkin akan damai diterima apabila ia menentang secara keras budaya yang mentradisi di tengah-tengah masyarakat. Oleh sebab itu dalam pengelolaan keagamaan yang paling penting ada adalah bagaimana tradisi itu "dijinakkan" melalui sistem nilai yang 
ada dalam budaya masyarakat itu. Justru itu, model-model pengeloloan keagamaan biasanya linear dengan memaknai budaya, akan menghasilkan penerimaan agama yang harmonis, sebaliknya apabila pengelolaan agama mengabaikan dan membelakangi makna budaya maka penerimaan pengelolaan itu berbanding terbalik dengan harmonisasi.

\section{Badikia}

Badikia berasal dari bahasa berzikir, merupakan suatu kegiatan yang dilaksanakan di surau atau masjid dalam rangka memperingati hari maulid nabi Muhammad. Dimana acara tersebut diperingati sepanjang bulan maulid bergantiganti di setiap suaru atau masjid. Badikia di surau dilaksanakan dengan sangat meriah, dimana masingmasing rumah membuat lamang kemudian di bawa kesurau. Malam kadang sampai zohor para urang siak melakukan zikir seperti berbalas pantun, mengalunkan puiji-pijian dan sekaligus bacaan-bacaan yang mengagungkan nabi Muhammad.

Pada cara zikir ini, hadir urang siak dengan sangat banyak, mereka duduk berbaris dan kemudian didengar oleh jemaah. Jemaah membawa nasi dengan bajamba, ada tiga kali acara makan bajamba sepanjang zikir itu dilakukan yakni makan malam, subuh dan siang.

Semua urang siak dan orang lakilaki yang hadir di surau ketika badikia itu makan bajamba bersama, mereka larut dengan kebersamaan. Di sini mereka saling mengenal tua dan muda dengan urang siaknya. Sebelum makan bersama pasti urang siak membacakan doa dan memberikan nasehat-nasehat, setelah itu barulah makan bersama.

Ritual ini kelihatan sekali sebagai media yang mengikat antara ulama dan umatnya, sehingga mereka memiliki kedekatan satu sama lain sehingga ia sulit untuk dipengaruhi oleh kedatangan para pendakwahpendakwah atau mubaligh yang tidak mereka kenal.

\section{Penerimaan Masyarakat Terhadap Mubaligh}

Berdasarkan adanya pendekatanpendekatan seperti uraian di atas, secara langsung atau tidak langsung elit-eltik agama atau mubaligh setempat sangat menerima mereka. Masyarakat memiliki kedekatan dengan mubalihg atau ulama yang sudah dikenalnya, sehingga ia sangat sukar untuk menerima kedatangan mubalihg-mubaligh dari luar. Tandikek sebagai nagari yang masih homogen, pada dasarnya tingkat responnya terhadap mubalihg sangat ketat, karena ulama yang memfasilitasi dalam masyarakat sudah sangat mereka kenal.

Penerimaannya sangat tergan-tung pada kesesuaian ajaran-ajaran dan tradisi yang sudah dipopulerkan dalam masyarakat. Pada umumnya, ulamaulama atau mubaligh yang ada dalam masyarakat Tandikek sudah memiliki kelaziman tradisi ritualisasi dalam beribadah dan sekaligus sudah ada ritual keagamaan yang diajarkan oleh ulama-ulama atau mubaligh yang sudah ada di Tandikek. 
Biasanya, seseorang yang akan menjadi elite agama seperti tuanku, labai dan seterusnya, diangkat secara resmi oleh masyarakat. Ada cara pengangkatannya yang disebut dengan maangkek ungku atau maangkek labai dan yang lainnya. Oleh sebab itu, seseorang yang akan menjadi elite agama di Tandikek tidak sembarangan dan tidak datang begitu saja, sehingga seseorang yang hendak melakukan dakwah di negeri ini sangat sulit diterima oleh masyarakat setempat.

Kondisi seperti ini sudah berlangsung sejak turun temurun, sehingga di Tandikek dikenal dengan labai nagari, labai surau atau ungku nagari atau ungku surau. Dengan demikian seseorang yang hendak mengembangkan dakwah atau pengajian di Tandikek maka ia harus lebih dahulu mendapatkan pelegalisasian seperti itu dari masyarakat, kalau tidak masyarakat tidak dapat menerimanya. Apalagi setelah gempa bumi ini masyarakat Tandikek sangat hati-hati sekali menerima mubaligh yang masuk.

Kenyataan seperti itu yang berlaku di Tandikek pada intinya menjadi filterisasi yang kuat bagi masyarakat dalam menerima dakwah-dakwah di daerah mereka sehingga tidak dapat seseorang datang berdakwah dengan begitu saja tanpa ada pendekatan dan pengangkatan yang resmi. Dalam berdakwah masyarakat Tandikek sudah memiliki tradisi baminggu yakni kegiatan pengajian yang berlangsung di surau yang sudah terprogram dalam satu kali seminggu dengan pendakwah yang sudah ditentukan, biasanya adalah ungku yang ada di nagari tersebut.

\section{Bentuk Dakwah yang Dilakukan}

Dakwah merupakan budaya komunikasi massa yang lahir semenjak Islam diterima oleh Nabi Muhammad. Dakwah mampu menjadi "alat" pembangun modal sosial umat Islam, sehingga Islam dapat diterima oleh masyarakat. Demikian juga dengan di nagari Tandikek. Agama itu diterima oleh masyarakat di sini tidak terlepas dari dakwah yang dilakukan oleh ulama. Ada beberapa paradigma dakwah yang dikembangkan oleh ulama di Tandikek, yakni ada paradigma dakwah teologis responsif yaitu meletakkan ide-ide Islam dengan realita konkret. Artinya, teologis Islam hadir ke tengah-tengah masyarakat untuk menjawab persoalan-persoalan yang dihadapi umat, kemudian persoalan itu di islamisasikan sesuai dengan tingkat pengamalan teologis mereka. Di sini letak peranan seorang ulama, ia hadir mengkomunikasikan pikiran-pikiran keislaman dengan bahasa ummah dengan gaya yang mudah dimengerti, kehadiran yang komunikatif ini jelas lebih dirasakan bersifat responsif. Responsibilitas banyak dimiliki oleh kelompok pemimpin agama yang memperhatikan sosiologis umatnya atau lokalitasnya, sehingga mampu mengkomunikasi teologis ke tengahtengah massa. Ia tidak berkutik dalam penekanan-penekanan esetorik, tetapi mampu juga membagun pencerahan eksetorik, sehingga pendidikan karakteristik itu tidak hanya dirasakan sebagai pencerahan bathiniah yang gersang dari moralitas realitas yang dihadapi. 
Ulama transformatif yang responsif itu di Tandikek bergerak melalui pendidikan dan pada umumnya memiliki lembaga pendidikan. Lembaga pendidikan ini pula yang memudahkan seorang ulama melakukan diffusi, transmisi dan internalisasi nilai-nilai sosial-kultural-relijius ke dalam masyarakat. Pada umumnya seorang ulama yang bergelar ungku di Tandikek memiliki surau tersendiri.

\section{Keterujian}

transformatifnya seorang ulama di Tandikek sangat ditentukan oleh kepemilikan surau tersebut. Seorang ulama di Tandikek pasti memiliki surau sebagai lokus aktivitasnya dalam menjalankan missi keulamaannya. Bahkan dalam persepsi masyarakat Tandikek, seorang ulama yang belum memiliki surau berarti keberadaannya sebagai seorang ulama di tengah-tengah masyarakat belum dapat diterima secara penuh. Perspsi ini terkonstruksi sejak dimulainya surau dijadikan sebagai lembaga pendidikan Islam pertama kalinya oleh Syeikh Burhanuddin pada abak ke-16 di Minangkabau. Dimana surau Syeikh Burhanuddin ini dapat dikatakan sebagai universitas terkemuka pada masa itu, karena ramainya anak-anak muda Minangkabau menintut ilmu di surau Burhanuddin di Ulakan Pantai Barat Pariaman. Disekitar surau Burhanuddin berdiri lebih 100 buah surau kecil tempat menginap santrisantri yang datang dari berbagai daerah dari Minangkabau. Realitas sejarah ini masih bisa dilihat bekasnya secara utuh di Ulakan sebagai pusat perkumpulan penganut tariqat satariyah di Minangkabau saat ini. Pandangan seperti ini terjadi di Tandikek karena ulama-ulama atau ungku di Tandikek beraliran tarikat yang sama dengan Syekh Burhanuddin yakni tarikat Syatariah. Dimana pada setiap bulan safar masyarakat Tandikek melakukan ritual basafa di Ulakan ditempat makamnya Syeikh Burhanuddin.

Kemudian, surau ini menjadi icon bagi setiap ulama di Tandikek. Seorang ulama identitik dengan keberadaan surau, sehingga surau menjadi intitusi pendidikan Islam yang monumental di Tandikek dan menjadi sebagai ruang ritual dan intelektual. Melalui intitusi inilah kiprah ulama transformatif mendesain pendidikan karakteristik yang merubah dunia sosial masyarakat Tandikek. Surau sebagai ruang ritual tidak terbatas oleh usia pengunjung atau jemaahnya, tetapi surau sebagai ruang intelektual merupakan surau dijadikan sebagai basis pendidikan intelektual anak muda. Dalam pendidikan surau itulah terjadi pengisian-pengisian ranah keintelektualan dan moralitas.

Ada strategi dakwah yang dilakukan oleh ulama atau ungku di Tandikek, diantaranya adalah:

\section{Membangun Prilaku Rujukan}

Di Tandikek ulama transformatif itu selalu menjadi rujukan dalam bertindak, berbuat dan melalukuan perubahan-perubahan. Hal ini terlihat dari tradisi-tradisi baik keilmuan-keintelektualan-tindakan sosial seorang ulama transformatif dibangun yang sama oleh muridmurid yang pernah belajar di surau ulama tersebut. Pengaruh yang paling signifikan lagi ulama trasformatif 
sebagai rujukan ini adalah, masyarakat sekitar kawasan surau tempat seorang ulama menjalankan peran dan fungsinya. Dimana seorang ulama dan suraunya menjadi icon sosial dalam satu kawasan. Ulama betul-betul menjadi rujukan dalam satu kawasan, sehingga teologis sosial kawasan sangat berkonotasi pada seorang ulama. Kedekatan dan pengaruh seorang ulama itu, terlihat lagi dari segi penamaan surau yang diberikan masyarakat, surau seorang ulama selalu diberi oleh masyarakat dengan nama kawasan dimana surau itu berada dan sekaligus surau itu menjadi simbol sosial sebuah kawasan. Sekaligus surau itu menjadi alat kontrol bagi masyarakat setempat dalam mencermati berbagai dinamika sosial. Hal ini dapat dilihat dari berbagai kegiatan dan ritual yang dilakukan di surau Tandikek, seperti adanya tradisi baminggu, basuluak dan seterusnya.

\section{Pendekatan Esetorik}

Pada hakikatnya kegiatan tariqat adalah salah satu cara bagi seorang ulama di Minangkabau untuk menginternalisasikan orientasi nilainilai normatif tersebut. Masalahnya, pendidikan karakteristik itu lebih banyak menyentuh pencerahan ranah bathiniah yang memerlukan internalisasi nilai-nilai. Dalam kondisi sekarang yang terjadi adalah bangsa ini kehilangan media-media internalisasi nilai-nilai itu, hingga tata laku berbanding terbalik dengan nilai normatif (agama, adat dan sebagainya).
Jika dilihat secara holistik, mulai dari tradisi sampai pada otoritas seorang ulama terhadap tariqat, maka dapat disimpulkan bahwa tariqat adalah sebuah media bagi ulama di Tandikek untuk membangun tata laku masyarakat, karena melalui tariqat jemaah atau komunitasnya dapat mengontrol diri sesuai dengan transmisi yang diberikan ulamanya. Di Tandikek, ulama di surau pada umumnya membangun jemaah tariqat dan sudah menjadi kelumrahan bagi setiap ulama menjadi "imam" tariqat dan pada umumnya tariqat yang berkembang di Tandikek tarikat satariyah.

Kegiatan atau ritualisasi tariqat itu pula menjadi kegiatan favorit bagi kalangan-kalangan usia tua dalam mengisi hari-hari tuanya di surausurau ulama. Diantara ritualitas tariqat yang menjadi kegiatan khas surau ulama transformatif adalah, suluk dan sembahyang empat puluh. Suluk merupakan pengontrolan diri terhadap hubungan manusia dengan Tuhannya. Hubungan ini pada dasarnya adalah menjelaskan hakikat hidup, seperti yang dijelaskan di atas. Sedangkan sembahyang empat puluh, merupakan shalat lima waktu yang dilaksanakan secara berjemaah selama empat puluh hari di surau yang imamnya langsung ulama pemilik surau tersebut. Kedekatankedekatan ulama dengan jemaah ini tidak dapat disangkal pula sebagai lokomotif untuk membangun dunia sosial yang bersinergi dengan nilainilai Islam sendiri. Strategisasi ini dibangun oleh seorang ulama ternyata memiliki keefektifan 
terhadap pengontrolan prilaku jemaah.

\section{Pendekatan Eksetorik}

Tugas yang paling menonjol dari seorang ulama di Tandikek adalah kemampuan menjawab atau menyahuti persoalan-persoalan masyarakatnya dengan ramah (bisa masuk akal menurut kemampuan masyarakat lokalnya yang masih sederhana). Di mana tugas seorang ulama tidak hanya berkutik pada ranah tektualitas tertapi juga melebar dalam kreasi-kreasi yang dapat menenangkan umat dari permasalahan.

Ulama di Tandikek menjabarkan hakikat hubungan manusia terhadap sesama, terlihat dari berbagai aktifitas dan nilai ajaran yang dilakukan oleh seorang ulama. Diantara yang paling mononjol adalah melakukan tradisitradisi keagamaan menjadi tradisi sosial sebegai perekat sosial masyarakat, misalnya melalui tradisi ziarah, tradisi tolak bala dan sebagainya. Tolak bala merupakan sesuatu tradisi yang dilakukan minimal satu kali dalam satu tahun menjelang masuknya bulan Ramdhan. Tolak bala ini dipimpin oleh ungku, urang siak dan diikuti oleh orang kampung mengelilingi kampung dengan mabawa obor dan membaca doa-doa. Kegiatan ini dilakukan setelah shalat maghrib. Tujuannya adalah supaya kampung halaman terhindar dari segala marabahaya dan dari hal-hal yang tidak diingini.
Ziarah dilakukan oleh masyarakat Tandikek di pimpin langsung oleh ungku atau ulamanya. Biasanya ziarah dilakukan ketempattempat ulama terkenal menjelang bulan Ramadhan. Di samping itu setiap bulan safar selalu berziarah bersama-sama ke Ulakan makam Syekh Burhanuddin.

Ulama di Tandikek juga terkenal dengan berbagai tradisi pemeliharaan alam, seperti membangun tradisi sungai terlarang, hutan terlarang, ikan terlarang dan sebagainya. Semunaya itu berkaitan langsung dengan penjagaan sikap manusia terhadap lingkungan alam sekitarnya. Di Tandikek ada ikan terlarang dimana masyarakat tidak berani memancing atau menangkap ikan itu sebelum larangannya di lepaskan. Satu kali setahun akan ada pesta melepaskan larangan itu yang mereka sebut dengan malapeh niat. Dimana masyarakat menangkap ikan ramairamai. Pada umumnya sungai-sungai yang ada di Tandikek ikannya adalah ikan larangan.

Begitu pula dengan orientasi persepsi manusia terhadap waktu, ulama di Minangkabau pada umumnya mampu menjelaskan zodiak-zodiak baik dan buruk sesuai dengan hitungan bulan qamariah. Petunjuk waktu turun ke sawah, waktu melaksanakan kegiatan yang baik, pada umumnya dapat dijelaskan secara sistematis oleh seorang ulama, sehingga tidak hayal seorang ulama sering didatangi oleh jemaahnya untuk berkonsultasi tentang penjelasan waktu ini, dengan tujuan 
kegiatan yang dilaksanakan tidak berlalu dengan sia-sia. Di Tandikek pemeliharaan zodiak ini sangat tergantung pada pendapat urang siak atau ungku.

Ulama di Tandikek pun, sebagai figur ekonom yang jujur dan sarat dengan keadilan. Hal ini terlihat dari usaha-usaha dagang yang dilaksanakan oleh ulama. Usahasuaha ekonomi dan dagang ulama di Tandikek dioperasionalkan oleh murid-muridnya atau orang lain, sedangkan ulama hanya menjadi kendali. Begitu pula dengan aset-aset pertanian yang dimiliki oleh ulama, semuanya diserahkan pada muridmuridnya yang berlajar di suraunya dan ulama hanya menerima sesuai dengan kesepakatan-kesepakatan yang dibuat oleh murid-muridnya yang belajar di suruanya. Bahkan dalam alur sejarah, lahirnya Minangkabau sebagai icon pedagang kaki lima merupakan hasil suport ekonomi surau yang dilaksanakan oleh murid-murid ulama di Minangkabau terutama pada era perkembangan surau sebagai institusi pendidikan oleh Syekh Burhanuddin pada abad ke-16. Dimana muridmurid yang belajar pada Burhanuddin, juga menjadi pedagang di lingkungan surau dan di pasarpasar terdekat dengan menggelar dagangan di atas tikar, tradisi itu berkembang menjadi sebuah tradisi di pasar-pasar tradisional di Minangkabau.

Dari alur orientasi eksetorik ini, dapat disimpulkan bahwa ulama trasformatif basis pendidikan karakteristiknya tidak hanya berkaitan dengan tata laku vartikal, tetapi juga terkait dengan pencerarahan tata laku horizontal, sebab bagaimana pun juga tata laku horizantal dan vartikel bahagian yang tidak terpisahkan dari pembentukan keparipurnaan tata laku manusia dalam membangun peradaban.

\section{KESIMPULAN}

Tandikek sebuah nagari yang jauh terletak di kaki gunung Tandikek, berhawa sejuk dan masyarakatnya yang sangat homogen. Pada tanggal 30 September 2009 daerah ini dilanda oleh bencana gempa bumi yang sangat dahsyat, sehingga sangat berpengaruh terhadap kehidupan ekonomi sosial masyarakatnya. Namun, satu hal yang tidak mengalami perubahan adalah sikap keagamaan masyarakat Tandikek yang masih sangat fanatik terhadap tradisi agama sudah berkembang dalam masyarakat dan sangat patuh kepada ulama tradisional yang diangkat dalam nagari ini.

Kepatuhan terhadap ulama tradisional ini dipengaruhi oleh adanya kemampuan ulama membangun komunikasi dengan masyarakat atau jemaahnya. Komunikasi yang dibangunnya berupa komunikasi transformatif dan teologis. Komunikasi itu dilakukan dengan sangat inten, karena banyak kesempatan antara ulama dan umatnya bertemu secara bersama.

Dengan kondisi seperti itu, sehingga masyarkat Tandikek tidak dengan mudah menerima dakwahdakwah yang datang dari mubalighmubaligh dari luar termasuk pasca 
gempa ini. Masyarakat Tandikek sangat sensitif dalam menerima seorang mubalihg yang masuk ke dalam wilayahnya. Keadaan yang seperti ini, kelihatannya menjadi salah satu bentuk proteksi keagamaan dalam masyarakat Tandikek, dimana masyarakatnya tidak mudah terpengaruh oleh aliran-aliran dari luar.

\section{REFERENSI}

Achidsti, S. A. (2014). Eksistensi Kiai Dalam Masyarakat. Ibda: Jurnal Kajian Islam Dan Budaya, 12(2), 149-171.

Asmaya, E. (2003). Aa Gym, Dai Sejuk Dalam Masyarakat Majemuk. Pt Mizan Publika.

Chariri, A. (2009). Landasan Filsafat Dan Metode Penelitian Kualitatif.

Gazali, G., \& Andy, N. (2017). Penguatan Nilai-Nilai Keagamaan Bagi Masyarakat Korban Bencana Gempa Di Kenagarian Tandikat Kecamatan Patamuan Kabupaten Padang Pariaman. Islam Realitas: Journal Of Islamic E Social Studies, 3(2), 133-148.

Geertz, C. (1960). The Religion Of Java. Glencoe, 11 L. Indonesia. Berkeley.

Gunawan, I. (2013). Metode Penelitian Kualitatif. Jakarta: Bumi Aksara.

Hidayatulloh, M. T., \& Farida, A. (2018). Kebutuhan Layanan Keagamaan Umat Khonghucu Di Dki Jakarta. Harmoni, 17(1), 118-136.
Hs, A. S. (2013). Tradisi Upacara Kematian Pada Masyarakat Nahdhiyyin Dalam Tinjauan Agama Dan Adat. Al-Adyan: Jurnal Studi Lintas Agama, 8(1), 127.

Johnson Doyle Paul. 1986. Teori Sosiologi Klasik Dan Modern. Pt. Gramedia. Jakarta.

Khoiriyah, N. (2017). Pandangan Sosial Ekonomi Dan Keagamaan Masyarakat Petani Di Jawa. Islamic Review: Jurnal Riset Dan Kajian Keislaman, 6(2), 233-247.

Miharja, D., Mulyana, M., Izzan, A., \& Zakaria, T. (2017). Ekspresi Keagamaan Masyarakat Betawi (Vol. 1). Lp2m.

Moleong, L. J., \& Edisi, P. (2007). Metodelogi Penelitian. Bandung. Pt. Remaja Rosdakarya.

Mulyadi, M. (2011). Penelitian Kuantitatif Dan Kualitatif Serta Pemikiran Dasar Menggabungkannya. Jurnal Studi Komunikasi Dan Media, 15(1), 128-137.

Munip, A. (2012). Menangkal Radikalisme Agama Di Sekolah. Jurnal Pendidikan Islam, 1(2), 159181.

Nelmaya, N. (2018). Proteksi "Elite Agama" Di Wilayah Gempa. Alhurriyah: Jurnal Hukum Islam (Alhurriyah Journal of Islamic Law), 12(2), 97-115. 
Patty, F. N. (2014). Resensi Buku: Sahidu, A., Muktasam, M., Nurjannah, Memahami Teori Ritual Catherine Bell Dan Fungsinya S., \& Hayati, H. (2018). 1. Bagi Studi Teologi (Hermeneutis). Gema Teologi, 38(2).

Parsons, T. 1959. General Theory In Sociology. Dlm. Merton (Pnyt.). Sociology Today, Hlm. 44-49. Usa: T.Pt.

Rais, M. (2010). Hegemoni Elit Dalam Ritus Agama Lokal: Studi Keberagamaan Masyarakat Bugis Bone Sulawesi Selatan. El Harakah, 12(2), 98.

Rakhmat, J. (2013). Psikologi Agama: Sebuah Pengantar. Mizan Pustaka.

Ritzer, G. \& Goodman, J. D. 2004. Modern Sociological Theory. Usa: McgrawHill. Analisis Rantai Nilai Kemiri Dan Strategi Pemberdayaan Petani: Studi Kasus Di Desa Batudulang Kecamatan BatulantehKabupaten Sumbawa. Jurnal Agrimansion, 19(1), 1-14.

Silfia Hanani. 2007. Peran Ulama Nusantara. Kuala Lumpur: Balai Bahasa Dan Pustaka Malaysia.

Suyuno, 2008. Metode Penelitian Pendidikan Dan Pengembangan. Bandung. Alafa Beta

Wekke, I. S. (2018). Islam Dan Adat, Keteguhan Adat Dalam Kepatuhan Beragama. Deepublish.

Yulisti, M., Kurniasari, N., \& Yuliaty, C. (2014). Analisis Keberlanjutan Lilifuk: Tinjauan Persepsi Masyarakat Lokal. Jurnal Sosial Ekonomi Kelautan Dan Perikanan, 9(1), 92-103. 